Original scientific paper

\title{
INNOVATIVE TECHNOLOGIES OF ALCOHOLIC BEVERAGES BASED ON FRUIT DISTILLATES
}

\author{
Elena V. Dubinina*, Darya V. Andrievskaya, Svetlana M. Tomgorova, Kantemir V. Nebezhev \\ All-Russian Scientific Research Institute of the Brewing, Non-Alcoholic and Wine Industry - \\ Branch of the V. M. Gorbatov Federal Research Center for Food Systems of RAS, Moscow, Russia
}

\section{KEY WORDS}

fruit raw material, ashberry, fermentation, maceration, fractional distillation, fruit distillates, alcoholic beverages

\begin{abstract}
One of the promising raw materials types for alcoholic beverages production, which have a peculiar aroma and taste, is the ashberry (red), widespread throughout the Russian Federation. The aim of the research was to develop an innovative technology for alcoholic beverages from the red ashberry based on the study of the raw materials biochemical composition transformation during its processing, maceration, fermentation, distillation, as well as its effect on the volatile components composition of distillate and the processing conditions of the finished alcoholic beverage. Fermented pulp of red ashberry, distillates and alcoholic beverage blends from ashberry were used as objects of the study. To determine the organoleptic and physico-chemical indicators in the work, standardized analysis methods and certified methods were used. The effect of various yeast races and fermentation conditions on the change in biochemical composition of the red ashberry pulp was studied. For this raw material type fermentation, recommended Siha 3 yeast race. The positive effect of the Vitamon Combi fermentation activator on the fermentation efficiency and the formation of qualitative characteristics of the fermented pulp, including its amino acid composition, is shown. It was established that the optimal conditions for fermentation is the anaerobic regimen at a temperature of no higher than $22^{\circ} \mathrm{C}$. The effect of fractional distillation operating parameters in a direct distillation unit on the volatile components' composition and concentration in ashberry distillate is studied. It is recommended to obtain a high-quality distillate to carry out the selection of the head fraction in the amount of $2.5 \%$ of the distilled pulp volume, and the selection of the tail fraction to start when the strength in distillate reaches $45 \%$ vol. It is shown that within 30 days of exposure in the distillate, a certain chemical equilibrium is achieved and its taste and aromatic characteristics are harmonized. The blending conditions of the alcoholic beverage are determined and the technological processing modes are established to ensure its high consumer properties. The conducted studies have allowed to develop innovative technology for a new alcoholic beverage from red ashberry.
\end{abstract}

\section{Introduction}

One of the priority areas for the development of the Russian alcohol market is to expand the range of wine products due to new types of high-quality alcoholic beverages made from domestic fruit raw materials. This area is becoming especially relevant in connection with changes in legislation relating to the production of wine products [1]. With a lack of industrial grape varieties production volumes intended primarily for the production of high-quality wines, in a significant part of the territory of the Russian Federation there is a sufficient amount of fruit raw materials, both cultivated and wild, suitable for the production of fruit wines, as well as alcohol beverages based on fruit distillates. According to Roskomstat [2], in 2019 the gross harvest of fruits (mainly apples) amounted to 2179.3 thousand tons, stone fruits -597.1 thousand tons, berry crops -701.8 thousand tons, and gross grapes harvest - only 678.0 thousand tons. Despite the fact that alcoholic beverages made from fruit raw materials, including calvados, fruit brandy and fruit vodka, are not inferior to brandy and cognac made from grapes in their consumer properties, the production of such products in our country is unreasonably small. At the same time, in recent years, there has been an increase in consumer interest in high-quality fruit vodkas, which differs from vodkas based on rectified spirit, with a peculiar aroma and taste inherent in the original fruit raw materials.

In European countries, such alcoholic beverages based on fruit distillates are widespread and are very popular. They are produced in accordance with Regulation (EU) No 110/2008 of the EUROPEAN PARLIAMENT AND THE COUNCIL of January 15, 2008 and are grouped according to the technology and composition of the raw materials into the following categories: «Eaude-vie de fruit», «Eau-de -vie de marc de fruit», «Eau-de-vie», «Geist» [3]. The technologies of these alcoholic beverages, as a rule, use methods of processing fruit raw materials, aimed at preserving in the finished product the unique taste and aroma inherent in this type of fruit or berries $[4,5,6,7,8]$, which allows them to be attributed to the elite alcohol segment.

The most famous liquor is Calvados, a liquor made from aged apple distillate. Calvados technology is identical to cognac technology $[9,10]$. For the high-quality calvados production, as well as for cognac, it is necessary to maintain the distillate in oak containers for a long time, which significantly increases the cost of the product. Unlike cognac and calvados, fruit vodkas are usually produced without aging or with minimal exposure, which increases their attractiveness to consumers. In the fruit vodkas production, various fruits and berries are used. Fruit vodka from apricots (Austria), cherries «Kirschwasser» (Germany), plums «Zwetchren Schnaps», «Pflaumen Schnaps» (Austria), «Mirabelle» (France), schnapps from blackberry, blueberry, gooseberry and juniper «Wacholderbeeren» (Austria), juniper vodka (Czech Republic, Poland, Slovakia, Slovenia), raspberry - «Framboise» (France) and others are very popular in Europe [4,10,11,12,13].

Due to the strict regulation in the current regulatory documentation of the main groups of volatile components and methanol contents, domestic alcoholic beverages made from fruit raw materials are significantly inferior in quality to their foreign counterparts. Usually they do not differ in bright aroma and taste and are used mainly in beverage blends with addition of aromatic components such as alcoholized juices, vanillin, almond oil, aromatic plants infusions, etc.

Researches conducted at All-Russian Scientific Research Institute of Brewing, Beverage and Wine Industry over the past few years have allowed the development of a number of innovative domestic technologies for distillates and spirits from various types of fruit raw materials $[14,15,16,17]$. The main criterias for 
choosing the raw material type were the degree of its distribution on the territory of Russia, both culturally and in wild form, as well as a high aromatic potential. When developing technologies for new types of alcoholic beverages, an integrated approach was taken to solve the posed problems: taking into account the biochemical composition of each type of fruit raw material, technological modes of its primary processing were developed, certain yeast races for fermentation, temperature fermentation modes were selected, optimal distillation regime parameters were developed that provide distillate enrichment with valuable volatile components, as well as at the blending stage, certain conditions were selected with alcoholic beverage, providing the aromatic potential of initial raw material [18,18,19,20,21].

One of the promising raw material types for the alcoholic beverages production with unique organoleptic characteristics is the ashberry of the mountain ash (Sorbus aucuparia L.), which is widespread throughout the Russian Federation. The fruits of wild plants with a significant sugar content (up to 12\%), as a rule, remain on trees and are not used in the food industry, therefore, can be considered as an additional raw material resource for the distillates and alcoholic beverages production. Previously, the biochemical composition of red ashberry was studied and its assessment was given in terms of suitability for the production of distillates and fruit vodkas based on them [22].

The purpose of this research was to develop an innovative technology for alcoholic beverages from the fruits of mountain ash (red) based on the study of the biochemical composition transformation of raw materials during its processing, maceration, fermentation, distillation, as well as its effect on the volatile components composition of the distillate and the processing conditions of the finished alcoholic beverage.

\section{Materials and methods}

As objects of research in the work were used: fermented pulp of red ashberry, distillates, alcoholic beverages blends (fruit vodka) from red ashberry.

To determine the organoleptic and hysic-chemical parameters of the objects of the study, standardized analysis methods were used, as well as methods developed by the institute's specialists and certified in the established manner [23,24,25,26,27].

A study of qualitative and quantitative composition of amino acids was carried out on an Agilent Technologies 1200 Series liquid chromatograph (Agilent, USA) equipped with a Luna 5 u C18 (2) chromatographic column $150 \times 4.6 \mathrm{~mm}$, stationary phase size $5 \mu \mathrm{m}$ (Phenomenex, USA) with pre-column.

Microbiological studies of the fermenting pulp state and the physiological yeast state during fermentation were carried out by direct microscopy using an MBI- 6 microscope with a 400 -fold increase. To count the number of yeast cells, a Goryaev counting chamber was used.

The yeast fermentation activity was determined by the amount of carbon dioxide released by the gravimetric method [28]. The fermentation efficiency was controlled by the formed ethyl alcohol amount.

\section{Results and discussion}

An important technological task in preparing fruit raw materials for distillation is the correct choice of yeast race for fermentation. In establishing the advantages of a particular race, not only the chemical composition of the raw material is important, but also its physical characteristics. As shown in the work [22], the organic acids concentration in the red ashberry is over $20 \mathrm{~g} / \mathrm{dm}^{3}$, which can inhibit the yeast development. In addition, the fruit pulp, unlike the wort, contains a large number of solid particles of the skin and pulp, which creates special conditions for yeast. Considering these factors, when preparing the red ashberry for chopping, they were pre-frozen at a temperature of minus $18^{\circ} \mathrm{C}$, kept at this temperature for 5-1 days, as a result of which the cell walls were destroyed, after which they were thawed and crushed to a homogeneous consistency. The resulting volume of pulp was diluted with the same volume of softened water $(1: 1)$. These operations were necessary in order to increase the permeability of the cell walls of the fruits, reduce titratable acidity and extract the maximum amount of soluble organic substances, including aromatizing.

The selection of Saccharomyces cerevisiae yeast for the experiment was carried out taking into account the characteristics of the used raw materials and according to the characteristics presented in the technical information of the manufacturer, from the collection available at All-Russian Scientific Research Institute of Brewing, Beverage and Wine Industry. The characteristics of 32 yeast races, used in winemaking for fermentation of fruit raw materials were studied, including 12 of them - yeast in the form of industrially produced preparations of imported active dry yeast (ADY). For research, the races SIHA aktivhefe 3 (Siha 3), Oenoferm C2 (Germany), Prime Arom, Red Fruit (Italy) were selected, according to their characteristics suitable for fermentation of fruit raw materials. As a control, a pure culture of Vishnevaya 33 (Cherry 33 ) yeast race was used, traditionally used to obtain wines from highly acidic fruits such as cherries and chokeberry [4].

One of the tasks when choosing yeast is to establish their adaptive ability to the fermented medium. To this end, the dynamics of changes in the number of living yeast cells during fermentation of the red ashberry pulp was studied (Figure 1).

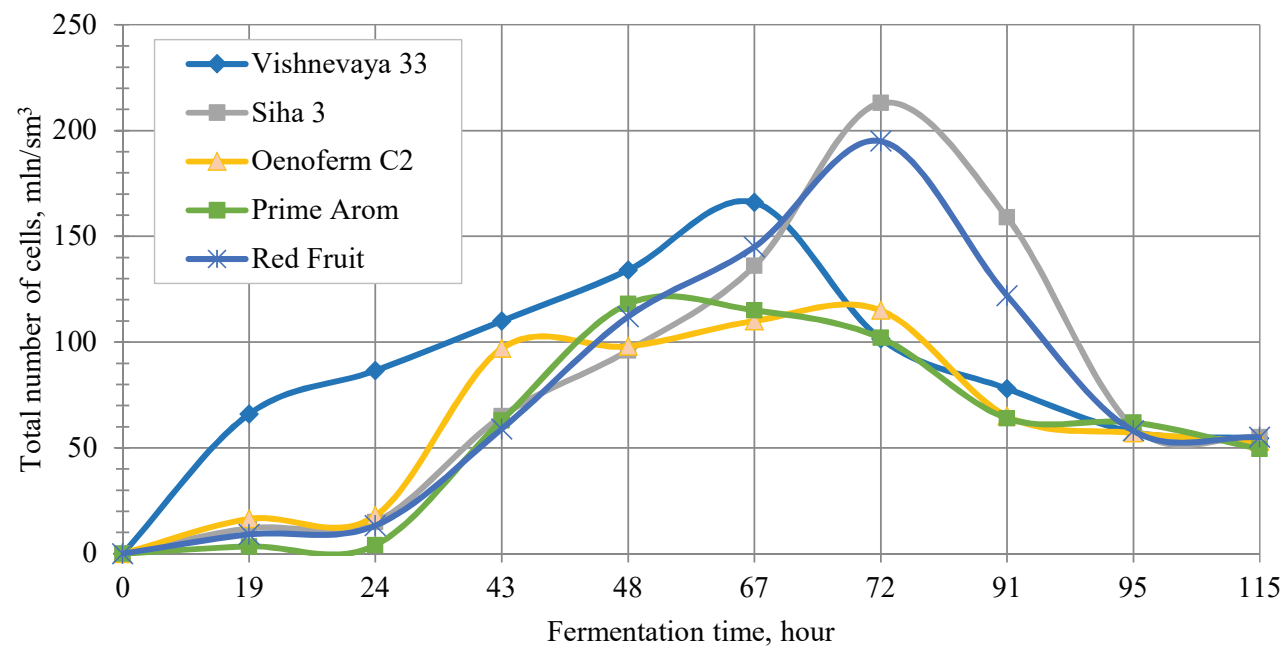

Figure 1. The dynamics of changes in the total number of living yeast cells during fermentation of the red ashberry pulp 
It was found that in the first 24 hours after the introduction of activated races in the form of ADY, the number of yeast cells changes insignificantly, which is explained by the lag phase in these yeasts, characterized by a noticeable increase in cell size and accumulation of nutrients in them [29]. The Vishnevaya 33 yeast race, which has gone through the lag phase during cultivation, introduced as a wiring, multiplies much more intensively in the first 24 hours. The number of the Vishnevaya 33 yeast race reached its maximum on the 3rd day of fermentation and then began to drop sharply, due to their death. During the period of the active fermentation phase (67-72 hours), the greatest accumulation of yeast cells was observed for all tested races of ADY. During this period, the maximum number of yeast cells was found in samples fermented using Siha 3 and Red Fruit yeast.

To characterize the yeast during this raw material type fermentation, the number of budding yeast cells was determined (Table 1).

It was found that already on the second fermentation day, the sample using the Siha 3 race contained the maximum number of budding yeast cells. Then the budding intensity decreased slightly, but by the end of the third fermentation day, the Siha 3 race accumulated the largest number of yeast cells, which ensured the rapid sugars fermentation in this sample.

It was established that the highest fermentation activity during red ashberry pulp fermentation under the same conditions was shown by Siha 3 yeast (Figure 2).

The Prime Arom and Oenoferm C2 races showed the same activity as Siha 3 in the initial fermentation period, however, after 20 hours of fermentation, their activity decreased. The dynamics of $\mathrm{CO}_{2}$ emission for the Vishnevaya 33 race was characterized by minimal values with a uniform character, and after 48 hours the fermentation rate noticeably decreased. The results allow us to recommend the Siha 3 race for the red ashberry pulp fermentation.
To accumulate large yeast biomass, which ensures the efficient sugars fermentation, the medium must contain nitrogen, both in inorganic (ammonium salt) and in organic form (peptides, amino acids) [29]. Amino acids play an important role in the yeast metabolism. Amino acids, in addition to building functions, can affect various functional systems of the cell, stimulating or inhibiting their activity. In the work [30], it was shown that the yeast Saccharomyces cerevisiae during alcohol fermentation is capable of producing a different amount of amino acids depending on the composition of the fermented medium. When studying the nitrogen complex of red ashberry, it was found that it have a relatively low concentration of free amino acids, and the content of important amino acids from the point of view of yeast nutrition such as isoleucine, valine and tryptophan is extremely low - from $1.1 \mathrm{mg} / \mathrm{dm}^{3}$ to $4.2 \mathrm{mg} / \mathrm{dm}^{3}$ [22]. In this regard, the effect of the Vitamon Combi fermentation activator (FA) on the red ashberry pulp fermentation process was studied. This supplement is a special nutrient substrate for yeast and consists of ammonium phosphate and thiamine. It was found that the addition of Vitamon Combi FA to the pulp positively affected the yeast growth and development - their total number and the proportion of budding cells increased significantly.

It was found that the introduction of additional nitrogen nutrition during fermentation of the red ashberry pulp leads to an increase in the content of free amino acids in fermented raw materials by $1.4-1.5$ times in comparison with samples fermented without FA (Table 2).

The obtained data allowed to conclude that when additional sources of nitrogen are added, the metabolism of the yeast cell changes, as a result of which new amino acids are produced. The fermented pulp significantly increases the content of aspartic acid, valine, methionine, phenylalanine, which are the precursors of aroma-forming volatile components (VC) of fruit distillates.

The yeast state monitoring during the red ashberry pulp fermentation

Table 1

\begin{tabular}{|c|c|c|c|c|c|c|c|c|c|c|}
\hline \multirow{3}{*}{$\begin{array}{l}\text { Fermentation } \\
\text { period, hour }\end{array}$} & \multicolumn{10}{|c|}{ Yeast race used } \\
\hline & \multicolumn{2}{|c|}{ Vishnevaya 33} & \multicolumn{2}{|c|}{ Siha 3} & \multicolumn{2}{|c|}{ Oenoferm C2 } & \multicolumn{2}{|c|}{ Prime Arom } & \multicolumn{2}{|c|}{ Red Fruit } \\
\hline & $\begin{array}{l}\text { total, } \\
\mathrm{mln} / \mathrm{cm}^{3}\end{array}$ & $\underset{\%}{\text { budding, }}$ & $\begin{array}{l}\text { total, } \\
\mathrm{mln} / \mathrm{cm}^{3}\end{array}$ & $\underset{\%}{\text { budding, }}$ & $\begin{array}{l}\text { total, } \\
\mathrm{mln} / \mathrm{cm}^{3}\end{array}$ & $\begin{array}{c}\text { budding, } \\
\%\end{array}$ & $\begin{array}{l}\text { total, } \\
\mathrm{mln} / \mathrm{cm}^{3}\end{array}$ & $\underset{\%}{\text { budding, }}$ & $\begin{array}{l}\text { total, } \\
\mathrm{mln} / \mathrm{cm}^{3}\end{array}$ & $\underset{\%}{\text { budding, }}$ \\
\hline 20 & 15.5 & 25.5 & 3.0 & 50.0 & 16.4 & 26.9 & 3.4 & 20.6 & 9.1 & 27.5 \\
\hline 26 & 19.0 & 30.0 & 5.4 & 59.3 & 17.9 & 28.5 & 4.0 & 32.5 & 13.3 & 29.0 \\
\hline 37 & 66.0 & 34.1 & 63.0 & 7.1 & 56.5 & 17.7 & 53.0 & 24.5 & 59.0 & 8.5 \\
\hline 42 & 74.5 & 31.5 & 75.0 & 8.0 & 70.5 & 23.4 & 70.5 & 21.3 & 69.0 & 9.4 \\
\hline 62 & 120.0 & 37.5 & 96.0 & 16.1 & 109.0 & 18.3 & 135.0 & 15.2 & 125.0 & 6.8 \\
\hline 72 & 140.0 & 33.6 & 150.0 & 16.7 & 145.0 & 17.4 & 101.5 & 22.7 & 130.0 & 11.5 \\
\hline 85 & 85.0 & 9.4 & 58.5 & 16.2 & 65.0 & 4.6 & 64.0 & 5.5 & 61.5 & 9.8 \\
\hline 92 & 67.0 & 7.4 & 54.5 & 15.8 & 56.0 & 3.9 & 61.5 & 4.1 & 57.5 & 7.8 \\
\hline
\end{tabular}

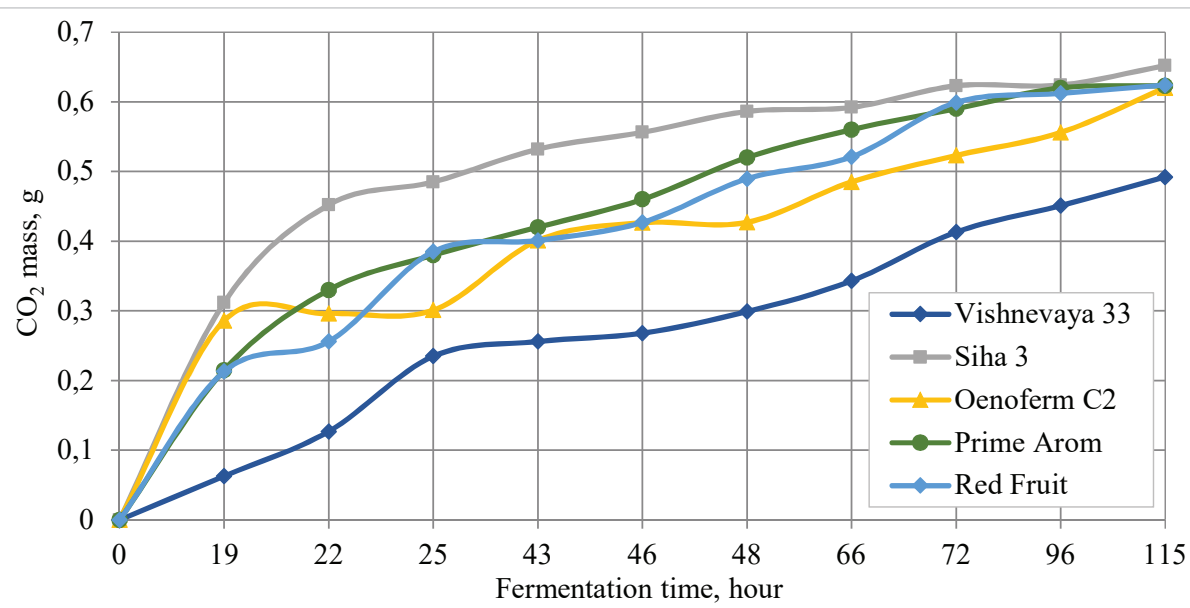

Figure 2. The dynamics of carbon dioxide in the process of red ashberry pulp fermentation 
Table 2

Effect of FA on the amino acid composition change in the pulp fermentation process

\begin{tabular}{|c|c|c|c|}
\hline \multirow{3}{*}{$\underset{\text { name }}{\text { Amino acid }}$} & \multicolumn{3}{|c|}{ Mass concentration, $\mathbf{m g} / \mathrm{dm}^{3}$} \\
\hline & \multirow{2}{*}{$\begin{array}{c}\text { before } \\
\text { fermentation }\end{array}$} & \multicolumn{2}{|c|}{ after fermentation } \\
\hline & & $\begin{array}{l}\text { without } \\
\text { activator }\end{array}$ & with activator \\
\hline Aspartic & $6.4 \pm 0.8$ & $1.8 \pm 0.2$ & $8.2 \pm 1.0$ \\
\hline Glutamine & $7.8 \pm 0.9$ & $6.6 \pm 0.8$ & $9.2 \pm 1.1$ \\
\hline Asparagine & $71.3 \pm 8.6$ & $1.4 \pm 0.05$ & $5.6 \pm 0.7$ \\
\hline Histidine & $7.9 \pm 0.9$ & $1.8 \pm 0.05$ & $0.6 \pm 0.07$ \\
\hline Serine & $32.6 \pm 3.9$ & $37.9 \pm 4.5$ & $49.2 \pm 5.9$ \\
\hline Glutamine & $15.4 \pm 1.8$ & $1.2 \pm 0.05$ & $6.3 \pm 0.8$ \\
\hline Arginine & $5.8 \pm 0.7$ & $0.5 \pm 0.02$ & $0.6 \pm 0.07$ \\
\hline Glycine & $2.2 \pm 0.2$ & $0.3 \pm 0.01$ & $1.6 \pm 0.2$ \\
\hline Threonine & $4.5 \pm 0.5$ & $5.9 \pm 0.7$ & $1.1 \pm 0.1$ \\
\hline Alanine & $1.7 \pm 0.1$ & $5.9 \pm 0.7$ & $0.6 \pm 0.07$ \\
\hline Tyrosine & $3.5 \pm 0.3$ & $0.5 \pm 0.05$ & $1.6 \pm 0.2$ \\
\hline Valine & $0.9 \pm 0.1$ & Not found & $0.6 \pm 0.07$ \\
\hline Methionine & $0.4 \pm 0.05$ & Not found & $1.2 \pm 0.1$ \\
\hline Tryptophan & $2.1 \pm 0.1$ & Not found & $3.2 \pm 0.4$ \\
\hline Isoleucine & $0.5 \pm 0.05$ & $0.6 \pm 0.05$ & $0.5 \pm 0.05$ \\
\hline Phenylalanine & $1.8 \pm 0.1$ & $0.9 \pm 0.1$ & $2.6 \pm 0.3$ \\
\hline Leucine & $1.4 \pm 0.1$ & Not found & $2.5 \pm 0.3$ \\
\hline Lysine & $4.5 \pm 0.5$ & $1.0 \pm 0.1$ & $4.2 \pm 0.5$ \\
\hline TOTAL & $170.8 \pm 20.5$ & $66.2 \pm 7.9$ & $99.2 \pm 11.9$ \\
\hline
\end{tabular}

In addition, the use of FA leads to an fermentation intensification, an increase in the efficiency of sugars fermentation and a decrease in the acetic acid synthesis (Table 3).
Table 3

The effect of nitrogen nutrition on the fermented pulp quality indicators

\begin{tabular}{lcc}
\hline \multirow{2}{*}{\multicolumn{1}{c}{ Indicator name }} & \multicolumn{2}{c}{ Fermentation conditions } \\
\cline { 2 - 3 } & $\begin{array}{c}\text { without } \\
\text { activator }\end{array}$ & $\begin{array}{c}\text { with } \\
\text { activator }\end{array}$ \\
\hline Volume fraction of ethyl alcohol,\% & $1.8 \pm 0.2$ & $2.2 \pm 0.2$ \\
\hline Mass concentration of sugars, $\mathrm{g} / \mathrm{dm}^{3}$ & $5.2 \pm 0.1$ & $4.0 \pm 0.1$ \\
\hline Mass concentration of volatile acids, $\mathrm{g} / \mathrm{dm}^{3}$ & $1.1 \pm 0.1$ & $0.4 \pm 0.1$
\end{tabular}

The introduction of Vitamon Combi FA into the pulp before fermentation also leads to an improvement in the organoleptic characteristics of the fermented raw materials - tones of fresh raw materials are more pronounced in the aroma, the taste becomes softer and more harmonious.

In order to develop optimal fermentation regimes, the influence of various fermentation conditions (temperature conditions, aeration) on the quality indicators of the fermented pulp was studied. The optimal conditions for this raw material type fermentation is the anaerobic regimen (without air access) at a temperature of no higher than $22^{\circ} \mathrm{C}$ (Table 4) was established. Such conditions provide high fermentation efficiency with minimal accumulation of volatile acids and methanol in the fermented pulp.

At the next work stage, in order to develop optimal distillation modes and obtain high-quality distillates, experimental distillations were carried out on a Kothe Destillationstechnik batch unit with different fractionation operating parameters: separation of different volumes of the head fraction, tail fraction was selected according to organoleptic indicators in the range of $55-50 \% \mathrm{vol}$. Based on a comparative analysis of the obtained distillates according to the organoleptic characteristics and composition of volatile components (VC), the following optimal modes of fractionated distillation of the fermented red ashberry pulp were determined: selection of the head fraction in the amount of $2.5 \%$ of the distilled pulp volume, the beginning of the tail fraction selection - when the distillate strength is reached $45 \%$ vol. (Table 5 ).

Table 4

The effect of aeration mode and temperature on the physicochemical composition of fermented ashberry pulp

\begin{tabular}{|c|c|c|c|c|}
\hline \multirow{3}{*}{ Indicators } & \multicolumn{4}{|c|}{ Fermentation Modes } \\
\hline & \multicolumn{2}{|c|}{ With periodic aeration } & \multicolumn{2}{|c|}{ No air } \\
\hline & $20 \pm 2^{\circ} \mathrm{C}$ & $24 \pm 2^{\circ} \mathrm{C}$ & $20 \pm 2^{\circ} \mathrm{C}$ & $24 \pm 2^{\circ} \mathrm{C}$ \\
\hline Fermentation duration, day & $5-6$ & $3-4$ & $5-6$ & $3-4$ \\
\hline Volume fraction of ethyl alcohol, \% & $1.9 \pm 0.2$ & $1.9 \pm 0.2$ & $2.3 \pm 0.2$ & $2.1 \pm 0.2$ \\
\hline Mass concentration of sugars, $\mathrm{g} / \mathrm{dm}^{3}$ & $2.5 \pm 0.1$ & $2.5 \pm 0.1$ & $2.0 \pm 0.1$ & $1.5 \pm 0.1$ \\
\hline Mass concentration of volatile acids, $\mathrm{g} / \mathrm{dm}^{3}$ & $0.8 \pm 0.1$ & $1.5 \pm 0.1$ & $0.4 \pm 0.1$ & $0.6 \pm 0.1$ \\
\hline Mass concentration of methanol, $\mathrm{mg} / \mathrm{dm}^{3}$ & $144 \pm 17$ & $252 \pm 30$ & $126 \pm 15$ & $181 \pm 22$ \\
\hline
\end{tabular}

The Influence of the head fraction volume on the quality characteristics of ashberry distillates*

Table 5

\begin{tabular}{|c|c|c|c|c|c|}
\hline \multirow{2}{*}{ Indicator Name } & \multicolumn{5}{|c|}{ The head fraction volume, \% of the distilled pulp volume } \\
\hline & 1.0 & 1.5 & 2.0 & 2.5 & 3.0 \\
\hline Volume fraction of ethyl alcohol, \% & 74.8 & 70.5 & 67.2 & 64.8 & 60.4 \\
\hline Distillate yield, \% from a. a. in fermented pulp & 86.4 & 85.7 & 84.8 & 83.6 & 78.5 \\
\hline Methanol, g/dm ${ }^{3}$ & 3.6 & 2.7 & 2.3 & 1.7 & 1.7 \\
\hline Mass concentration of volatile acids, $\mathrm{mg} / 100 \mathrm{sm}^{3}$ of a. a. & 19.8 & 15.5 & 12.0 & 11.3 & 11.5 \\
\hline VC amount, $\mathrm{mg} / \mathrm{dm}^{3}$ of a. a., including: & 6245 & 5812 & 4600 & 3953 & 3550 \\
\hline — carbonyl compounds & 1240 & 980 & 560 & 410 & 217 \\
\hline - higher alcohols & 3715 & 3652 & 3187 & 3125 & 2978 \\
\hline - esters & 1280 & 1170 & 830 & 386 & 320 \\
\hline - $\beta$-phenylethyl alcohol & 10 & 10 & 23 & 32 & 35 \\
\hline Tasting score & 6.8 & 7.0 & 7.5 & 8.0 & 7.8 \\
\hline
\end{tabular}

* The table shows the average values of three measurements 
Despite the fact that an increase in the volume of the selected head fraction leads to a slight decrease in the volume fraction of ethyl alcohol and the yield of distillate, its organoleptic characteristics significantly improve, which is obviously associated with a decrease in the concentration of carbonyl compounds and ethyl acetate.

The taste and aroma of any distillate immediately after its receipt remotely resemble the taste and aroma of the finished product. As a result of significant changes in the chemical composition of raw materials due to fermentation and distillation, new substances are formed, which, during aging, continue to participate in redox reactions with a gradual change in the taste and aromatic properties, reaching an equilibrium state. In this regard, the dynamics of the volatile components transformation of the obtained distillate was studied in order to determine the optimal duration of rest (aging) before blending (preparation) of the beverage. For this, the distillate was kept at a temperature from $21^{\circ} \mathrm{C}$ to $25^{\circ} \mathrm{C}$ for 3 months under conditions excluding direct sunlight. As a result, it was found that with an increase in the aging time, a qualitative and quantitative composition of the volatile components changes (Table 6).

The most significant changes occur during the first month of exposure - the concentration of higher alcohols and methanol decreases, while the content of carbonyl compounds and esters slightly increases.

Influence of the rest duration on the composition of the main volatile components of the red ashberry distillate*

\begin{tabular}{|c|c|c|c|c|}
\hline \multirow{2}{*}{ Component Name } & \multicolumn{4}{|c|}{ Mass concentration, $\mathrm{mg} / \mathrm{dm}^{3}$ of a. a. } \\
\hline & 10 days & 30 days & 60 days & 90 days \\
\hline Methanol, $\mathrm{g} / \mathrm{dm}^{3}$ of a. a. & 1.7 & 1.6 & 1.6 & 1.6 \\
\hline Acetaldehyde & 405 & 421 & 424 & 427 \\
\hline Ethyl acetate & 309 & 345 & 350 & 352 \\
\hline 1-propanol & 904 & 878 & 870 & 862 \\
\hline Isobutanol & 1032 & 997 & 985 & 982 \\
\hline Isoamylol & 1240 & 1194 & 1180 & 1175 \\
\hline Ethylcaproate & 2 & 5 & 5 & 6 \\
\hline Hexanol & 41 & 34 & 31 & 30 \\
\hline Ethyl lactate & 48 & 45 & 40 & 42 \\
\hline Ethylcaprylate & 9 & 16 & 21 & 22 \\
\hline Ethylcaprate & 13 & 26 & 30 & 31 \\
\hline Phenylethyl alcohol & 32 & 24 & 24 & 19 \\
\hline $\begin{array}{l}\text { VC amount excluding methanol, } \\
\mathrm{mg} / \mathrm{dm}^{3} \text { of a. a., including } * * * *\end{array}$ & 3953 & 4038 & 4011 & 3995 \\
\hline - carbonyl compounds & 410 & 433 & 440 & 441 \\
\hline - higher alcohols & 3255 & 3138 & 3096 & 3076 \\
\hline - esters & 386 & 443 & 451 & 459 \\
\hline
\end{tabular}

* The table shows the average values of three measurements.

** In this table, when calculating the volatile components amount, all identified impurities were taken into account, some of them are not included in the illustrative material.

The revealed changes in individual volatile components concentration are associated primarily with redox reactions involving dissolved oxygen in the distillate. The decrease in the concentration of higher alcohols is probably caused not only by their oxidation, but also by binding to higher fatty acids to form the corresponding esters [10,31].
The objective of the next research stage was to determine the optimal qualitative and quantitative composition of alcoholic beverages blends and to develop optimal parameters for their technological processing and aging (rest). For this purpose, pilot blends samples with various conditions in terms of the volume fraction of ethyl alcohol and the mass concentration of sugars were prepared and their organoleptic evaluation was carried out with the participation of leading specialists from All-Russian Scientific Research Institute of Brewing, Beverage and Wine Industry. The blends included: ashberry distillate, softened water with a hardness of not more than $0.2^{\circ} \mathrm{e}$, sugar syrup made from refined sugar, with a sugars mass concentration of $650 \mathrm{mg} / \mathrm{dm}^{3}$. As a result of the tasting, the optimal conditions of the alcoholic beverage from red ashberry were selected: the volume fraction of ethyl alcohol was $42 \%$, and the mass concentration of sugars was $5.0 \mathrm{~g} / \mathrm{dm}^{3}$.

When testing the experimental beverage samples for a tendency to turbidity of a physicochemical nature, it was established that as a result of cooling to a temperature below minus $5{ }^{\circ} \mathrm{C}$, light opal appeared in the samples. To remove clouding agents, the test beverage samples were cold treated at a temperature of minus $12{ }^{\circ} \mathrm{C}$ for 24 hours to 120 hours and then filtered through a membrane filter with a pore rating of $0.45 \mu \mathrm{m}$. Processing within 24 hours was sufficient to achieve bottling resistance. After filtering, the beverage blends were transparent, with shine, without sediment and foreign inclusions.

The research results allowed us to develop a technology for red ashberry alcoholic beverage, that provides competitive domestic products. The introduction of new technology in production will not only expand the range of high-quality alcoholic beverages from local fruit raw materials, but also solve a number of socio-economic problems, including the rational use of local raw materials, as well as the creation of new enterprises that provide employment in the agricultural sector of the economy.

\section{Conclusion}

The studies made it possible to establish the effect of various yeast races and fermentation conditions on change in the biochemical composition of the red ashberry pulp and to determine the Siha 3 yeast race most suitable for fermentation of this raw material type. The positive effect of the Vitamon Combi fermentation activator on the fermentation efficiency and formation of qualitative characteristics of the fermented raw material is shown. It was established that the optimal conditions for the fermentation of this raw material type is the anaerobic regimen at a temperature of no higher than $22^{\circ} \mathrm{C}$. The effect of fractional distillation operating parameters on a batch direct-batch unit on the composition and concentration of volatile components in the ashberry distillate is studied. It is recommended to obtain a high-quality distillate to carry out the selection of the head fraction in the amount of $2.5 \%$ of distilled pulp volume, and the selection of the tail fraction to start when strength in the distillate reaches $45 \%$ vol.

Certain regularities of changes in the volatile components mass concentration in the ashberry distillate were established during aging and it was shown that basic physical and chemical processes take place within 30 days, as a result of which a certain chemical equilibrium is achieved in the distillate and its flavor and aromatic characteristics are harmonized.

The conducted studies have allowed to develop the innovative technology for a new alcoholic beverage from red ashberry.

\section{Acknowledgment}

The article was published as part of the research topic No. 0585-2019-001 of the state assignment of the V. M. Gorbatov Federal Research Center for Food Systems of RAS. 


\section{REFERENCES}

1. Federal law of December 27, 2019 No. 468-FZ «On viticulture and winemaking in the Russian Federation» [Electronic resource: http://www.consultant. ru/document/cons_doc_LAW_341772/ Access date 08.04.2020] (In Russian)

2. Gross harvest of fruits, berries, grapes, tea leaves and hops in the Russian Federation. [Electronic resource: https://www.gks.ru/enterprise economy/ Access date 08.04.2020] (In Russian)

3. Oganesyants, L.A., Panasyuk, A.L. (2009). Technical regulation of the wine products and spirits production and turnover. European Union Regulations. Moscow: Industrial consulting group «Razvitiye». - 200 p. ISBN: 978-5-904421-01-4 (In Russian)

4. Oganesyants, L.A., Panasyuk, A.L., Reytblat, B.B. (2011). Theory and practice of fruit winemaking. Moscow: Industrial consulting group «Razvitiye». - 396 p. ISBN: 978-5-904421-03-8 (In Russian)

5. Oganesyants, L. A., Reitblat, B. B., Peschanskaya, V. A., Dubinina, E. V. (2012). Scientific aspects of ardent spirits production from fruit raw materials. Winemaking and Viticulture, 1, 18-19. (In Russian)

6. Werner Albrecht, W., Dürr, P., Gössinger, M., Hagmann, K., Pulver, D., Scholten, G. (2010). Scholten technology of the fruit distillery. Germany: Ulmer Eugen Verlag - 326 p. ISBN: 9783800148998 (In German)

7. Balcerek, M., Pielech-Przybylska, K., Patelski, P., Dziekońska-Kubczak, U., Strąk, E. (2017). The effect of distillation conditions and alcohol content in 'heart' fractions on the concentration of aroma volatiles and undesirable compounds in plum brandies. Journal of the Institute of Brewing, 123(3), 452-463. https://doi.org/10.1002/jib.441

8. González, E.A., Fernández, I.O., Castro, L.P., Guerra, N.P. (2016). Production and characterization of a novel distilled alcoholic beverage produced from blueberry (Vaccinium corymbosum L.). Fruits, 71(4), 215-220. https://doi.org/10.1051/fruits/2016013

9. Tanner, H., Brunner, H.R. (2007. Fruit distillery today - a guide for small distillers. Hall: Heller chemistry and administration. -250 p. (In German)

10. Li, A.G.H., Piggott, J. R. (2006). Alcoholic beverages: Features of fermentation and production. New York, Boston, Dortreich, London, Moscow: Kluwer Akademic / Plenum Publishers. - 552 p. ISBN: 0-306-47706-8

11. Balcerek, M., Pielech-Przybylska, K., Patelski, P., Sapińska, E., Księżopolska, M. (2013). The usefulness of intermediate products of plum processing for alcoholic fermentation and chemical composition of the obtained distillates. Journal of Food Science, 78(5), S770-S776. https://doi. org/10.1111/1750-3841.12097

12. Miličević, B., Babić, J., Šubarić, D., Ačkar, D., Jozinović, A, Miličević, R, Klarić, I. (2014). The effect of the fermentation with immobilized yeast and different cherry varieties on the quality of cherry brandy. Croatian journal of food science and technology, 6(2), 104-109. https://doi.org/10.17508/ CJFST.2014.6.2.06

13. Urošević, I., Nikićević, N., Stanković, L., Anđelković, B., Urošević, T., Krstić, G., Tešević, V. (2014). Influence of yeast and nutrients on the quality of apricot brandy. Journal of the Serbian Chemical Society, 79(10), 1223-1234. https://doi.org/10.2298/jsc140125024u

14. Oganesyants, L.A., Peschaskaya, V.A., Dubinina, E.V., Loryan, G. V. The method of obtaining mulberry distillate. Patent RF, no. 2560266, 2015. (In Russian)

15. Oganesyants, L.A., Peschaskaya, V.A., Loryan, G.V., Dubinina, E. V. Method for the alcoholic beverage from fruit raw materials production. Patent RF, no. 2591530, 2016. (In Russian)
16. Oganesyants, L.A., Peschaskaya, V.A., Dubinina, E. V. Method for the blackcurrant distillate production. Ppatent RF, no. 2609659, 2017. (In Russian)

17. Oganesyants, L.A., Peschaskaya, V.A., Dubinina, E.V., Nebezhev, K.V. (2019). Development of tangerine fruits distillate technology. Current issues in the beverage industry, 3, 156-161. https://doi.org/10.21323/9785-6043128-4-1-2019-3-156-161 (In Russian)

18. Oganesyants, L.A., Peschaskaya, V.A., Dubinina, E.V., Trofimchenko, V.A. (2014). Development of requirements to pear distillate for the production fruit brandy. Storage and processing of farm products, 1, 36-38. (In Russian)

19. Krikunova, L.N., Dubinina, E.V., Alieva, G.A. (2016). The influence of yeast race on the fermentation of cherry pulp for producing distillate. Food Processing: Techniques and Technology, 1, 24-31. (In Russian)

20. Oganesyants, L.A., Peschaskaya, V.A., Dubinina, E.V. (2017). Development of innovative blackcurrant distillate technology. II International Scientific and Practical Conference «Innovative research and development for scientific support of the production and storage of environmentally friendly agricultural and food products», 426-428. (In Russian)

21. Dubinina, E.V., Osipova, V.P., Trofimchenko, V.A. (2018). Influence of preparation method on volatile compounds content and output of distillates from raspberry. Beer and beverages, 1, 30-34. (In Russian)

22. Oganesyants, L.A., Peschaskaya, V.A., Dubinina, E.V., Trofimchenko, V.A. (2016). Assessment of technological properties of rowan for production of alcoholic beverages Storage and processing of farm products, 9, 19-22. (In Russian)

23. GOST 33834-2016. «Wine production and raw materials for its production. Gas chromatographic method for determining the mass concentration of volatile components». Moscow: Standartinform. 2016. - 11 p. (In Russian)

24. GOST 32095-2013. "Alcoholic products and raw materials for their production. Method for determining the volume fraction of ethyl alcohol». Moscow: Standartinform. 2014. - 5 p. (In Russian)

25. GOST 32001-2012. «Alcoholic products and raw materials for their production. Method for determination of mass concentration of volatile acids». Moscow: Standartinform. 2014. - 5 p. (in Russian)

26. GOST R32051-2013. «Wine production. Methods of organoleptic analysis». Moscow: Standartinform. 2013. - 13 p. (In Russian)

27. Method of measuring the mass concentration of free amino acids in alcoholic and non-alcoholic beverages by high-performance liquid chromatography. Certificate of attestation № 01.00225/205-48-12, 2012 (In Russian)

28. Ilyashenko, N.G., Scherbakov, S.S. (2005). Guidelines for the implementation of laboratory work in the discipline «Microbiological foundations and control of wine production». Moscow: Moscow State University of Food Production. - 42 p. (In Russian)

29. Buryan, N.I. (1997). Microbiology of winemaking. Yalta: Institute of Viticulture and Winemaking «Magarach». -431 p. (In Russian)

30. Khalilova, E.A., Kotenko, S.T., Islammagomedova, E.A. (2011). formation of free amino acids in yeast saccharomyces cerevisiae Y-503 in process of ethanol biosynthesis. Izvestia of Samara Scientific Center of the Russian Academy of Sciences, 13, (1-5), 1164-1166. (In Russian)

31. Lukic, I., Miličević, B., Tomas, S., Radeka, S., Peršurić Đ. (2012) Relationship between volatile aroma compounds and sensory quality of fresh grape marc distillates. Journal of the Institute of Brewing, 118(3), 285-294. https://doi.org/10.1002/jib.39

\section{AUTHOR INFORMATION}

Elena V. Dubinina - candidate of technical sciences, leading researcher, Department of spirits, All-Russian Scientific Research Institute of Brewing, Beverage and Wine Industry - Branch of V. M. Gorbatov Federal Research Center for Food Systems of RAS, 119021, Moscow, Rossolimo str.,7. Tel.: +7-903-577-53-62, e-mail: elena-vd@yandex.ru

ORCID: https://orcid.org/0000-0002-8364-9539

*corresponding author

Darya V. Andrievskaya - candidate of technical sciences, researcher, Department of spirits, All-Russian Scientific Research Institute of Brewing, Beverage and Wine Industry - Branch of V. M. Gorbatov Federal Research Center for Food Systems of RAS, 119021, Moscow, Rossolimo str.,7. Tel.: +7-906-753-84-28, e-mail: dashaand-mail@rambler.ru

ORCID: https://orcid.org/0000-0001-5167-9074

Svetlana M. Tomgorova - candidate of technical sciences, researcher, Department of spirits, All-Russian Scientific Research Institute of Brewing, Beverage and Wine Industry - Branch of V. M. Gorbatov Federal Research Center for Food Systems of RAS, 119021, Moscow, Rossolimo str.,7. Tel.: +7-916-771-58-97, e-mail: ryabovasm@gmail.com

ORCID: https://orcid.org/0000-0002-6913-9006

Kantemir V. Nebezhev - junior researcher, Department of spirits, All-Russian Scientific Research Institute of Brewing, Beverage and Wine Industry - Branch of V. M. Gorbatov Federal Research Center for Food Systems of RAS, 119021, Moscow, Rossolimo str.,7. Tel.: +7-996-916-91-11, e-mail: kantemir111@yandex.ru ORCID: https://orcid.org/0000-0002-3828-4737

All authors bear responsibility for the work and presented data.

All authors made an equal contribution to the work.

The authors were equally involved in writing the manuscript and bear the equal responsibility for plagiarism.

The authors declare no conflict of interest

Received 27.04.2020 Accepted in revised 08.05.2020 Accepted for publication 15.05.2020 